\title{
Youth Becoming Addict of Cannabis and its Advancement at the Cost of Health
}

\author{
Himanshu Yadav', Mahipal Singh Sankhla ${ }^{2 *}$, Rajeev Kumar ${ }^{3}$ \\ ${ }^{1}$ Student of M.Sc. Forensic Science, Division of Forensic Science, Galgotias University, Greater Noida \\ ${ }^{2}$ Research Scholar, Division of Forensic Science, Galgotias University, Greater Noida \\ ${ }^{3}$ Associat Professor, Division of Forensic Science, Galgotias University, Greater Noida
}

*Corresponding Author: Mahipal Singh Sankhla, Research Scholar, Division of Forensic Science, Galgotias University, Greater Noida, Email: mahipal4n6@gmail.com

\begin{abstract}
Cannabis is an emerging drug smoked by Indian youth on large scale. Its adverse effect of hallucination making youth psychologically dependent of the drug. It is harmful in any form whether Bhang, Ganja, Charas or hashish, Sinsemillia and Majun. All are procured of Cannabis Sativa and the alkaloid is Delta-9-tetrahydrocannabinol (THC) most psychoactive cannabinoid. Studies divulged that 2-3mg of THC inhaled and 5-20mg ingested THC can cause attention impairment, short term memory. Also its effects varies from person to person or gender. A large number of youth in India is addict of THC because it is easily available in market. Here, in this review of effects of cannabis on youth we made an attempt on focusing the main issues that why youth is becoming an doper of marijuana as well as engaging in major criminal activities like drug peddling, violence, sexual assault, rape. In many studies it has been seen that the effects of cannabis makes an individual mentally as well as physically weak. It is a curse for the young generation because of its intake, they are entering in the world of crime in very young age. Usually, marijuana smoked by saints and they call themselves devotee of Lord Shiva.
\end{abstract}

Keywords: Cannabis, Marijuana, Youth, Effect, Tetrahydrocannabinol (THC), etc.

\section{INTRODUCTION}

The cannabis, also called hemp plant has been in existence on earth since eternity and grows well in almost everywhere in this world, but has been known chiefly as a reservoir of fibre for the fabrication of textiles and rope [1]. Cannabis derived term of the plant Cannabis sativa, Cannabis indica and, of venial implification Cannabis ruderalis [2]. Most of the people smoke marijuana in hand-rolled cigarettes called joints; in pipes, water pipes (sometimes called bongs), or in blunts (marijuana rolled in cigar wraps)[3]. The most regularly used illicit drug is Marijuana (22.2 million population has smoked this in past three years) in comformity with the 2015 National Survey on Drug Use and Health [4]. In $12^{\text {th }}$ graders, the rate of use were maximum still: $35.6 \%$ had smoked marijuana during the year former to the assess and $2205 \%$ used in the past month; $6.0 \%$ said they used marijuana everyday or near-daily [5].

\section{CANNABINOIDS}

Cannabinoids are a stock of miscellaneous chemical blend that moderate neurotransmitter discharge in the brain by action on cannabinoid receptors in the cells [6]. The prime psycho active component in cannabis distil is THC, cannabis consists at least 489 chemical compounds, 70 of which are cannabinoids. The figure of these cannabinoids have expanded from 70 to 104 categorized in entire herb from 2005 to present, and other identified compounds in the herb expanded from 400 to 650 [7].

There are a number of extents that cannabis consists of cannabinoid carboxylic acid, which deficit psychoactive crap until they are tempestuous, when they alter into a dynamic manifestation of THC [8]. Mainly deduced Cannabinoids from 3 sources: (a) Phytocannabinoids are cannabinoid complexes produced by herbs Cannabis indica or Cannabis sativa (b) Synthetic cannabinoids, synthesized in the laboratory, are configurationally analogous to phytocannabinoids or endocannabinoids and deed by almost identical biological contrivance (c) Endocannabinoids are neurotransmitters generated in the brain or in tangential tissues, and deed on cannabinoid receptors [9]. Medicinal use of Cannabinoids 
(e.g. for supervision of spasticity in various sclerosis or nausea in the course of action of cancer chemotherapy) [6].

\section{Pharmacokinetics}

Cannabinoids can be administered by a variety of routes. Within few minutes, utmost quantity of THC can be liberated into blood by inhalation or smoking, uttermost at 15-30 minutes, and slacken within 2-3hours [9]. Smoked cannabis turn out intoxication that undying from one to three hours, and provides substantially extra THC into the bloodstream than oral ingestion of the drug. ${ }^{3}$ Laggard and changeable absorption resulted by oral oversight, with a natural accessibility of $10 \%$ to $20 \%$, and generally lesser than 15\% [10]. THC pharmacokinetics and paraphernalia diversify as a purpose of the weight of a cannabis cigarette its proceedings, the concentration of other cannabinoids, the pace of inhalation, extent and duration of puffs, amount inhaled, magnitude of breath-holding, cardinal volume, break out smoke and quantity titration [11]. In crude cannabis, much of the total THC is not free THC but THC acid [12]. The warmth just in front of the forwarding zone of combustion in a cigarette or pipeful of cannabis alter the THC acid to free THC [13] and the combustion of cannabis transform it into vapour state so that the vapours can inhaled deeply in lungs. Rather than smoking, reduced temperature vapourisation of cannabis has been postulated safer, as it may provide fewer high molecular weight components than smoked cannabis [14]. The 72 hour cumulative discharge of total metabolites, stated as a percentage of the conducted quantity, amounts to $13 \%$ to $17 \%$ in the urine and $25 \%$ to $30 \%$ in the feces after intravenous administration or smoking, but the fecal discharge rises to $48 \%$ to $53 \%$ after oral ingestion [10]. THC can also be altered to a hemisuccinate and run as a rectal suppository [15]. THC can be ascertain in blood during a month of steady abstinence, in heavy chronic cannabis users [16]. These results are in conformance with THC lipophilicity and time course of persisting neurocognitive impairment seen in earlier researches [17]. The gratifying gears of cannabis may be due to rise of serotonin, while GABA is accountable for retention loss encourage by THC, as well as emphasis [18].

\section{Toxic EfFects on Human Health}

In terms of short-term aftermath of cannabis on the body, it can consists the impairment of blood vessels resulted by the smoke [19]. Slowdown of blood pressure can cause people to faint or pass out, is also a effect of cannabis. It results in inflate of heart rate, which can be a threat for persons with heart problems and can results in heart attack [20]. Some data urge that a person's threat of heart attack during the first hour after smoking marijuana is nearly five times his or her usual risk [21]. Researches have suggested a fine bond between marijuana utilize in adolescence and inflate threat for combative form of testicular cancer that prevalently scourge young adult males [22].

\subsection{Effects on Brain}

In the brain and tangential tissues, the depicted receptor is $\mathrm{CB} 1$. It has various task in both locales [23]. Brain imaging researches contrasting school students who are scheduled long-term cannabis addict and non-using students normally find poorer cognitive execution and heavy shrink in perfusion in the prior using SPECT scans [24]. These substitutions could restrictedly define the downgrade educational attainment and downgrades amid persistent or chronic cannabis users [25]. It can also damage the aptitude of sensible and taking of arbitration, memory, converge and also intelligence level (IQ) [26].

\subsubsection{Central Nervous System}

As a Central Nervous System (CNS) depressant, the cannabis operate vitally [27]. The most vigorous gear on short-term episodic and efforting memory, layout and resolution making, feedback fleetness, preciseness and latency, these all a handful components of cognitive concern are damaged by cannabis [28]. Poorer complex concentration performing as well as lagging psychomotor velocity, poorer series ability and trouble in enunciated story memory can be seen in teens who carry on to administer the cannabis critically [29]. Drowsiness and contraction of activeness develops by cannabis, being synergistic with alcohol, barbiturates and other CNS depressants in this regard [30]. It is strived at $\mathrm{CB} 1$ receptors in the medial grey substance, and local injection of THC or its mock analogues at this spot is efficacious in alleviating ache [31]. Complex human instrument effectuation can be impaired as long as $24 \mathrm{~h}$ after smoking a reasonable quantity of cannabis and the consumer may be unmindful of the drug's impact [32].

\subsubsection{Neurobiology of Cannabis}

There are only two genre of cannabis receptors have been diagnosed on which THC acts: type 1 
(CB1) and type 2 (CB2) cannabinoid receptors [6]. CB1 receptors are ameliorate in the cerebellum (cognition, coordination), hippocampus (erudition and memory), cortex (cognitive purpose, supervision charge and command, integration of sensory input), basal ganglia (motor control, planning) ventral striatum (forecast and perception of favour), amygdala (disquiet, sensation, dread), hypothalamus (craving, hormone levels, libido power), brain stem and spinal cord (vomiting, pain) [33-36]. Drugs that chunk the influence of CB1 receptors chunk the cannabis intoxication in humans and stop animals from selfadministering cannabis [37, 38]. Earlier onslaught users displays huge damage in cognitive province, consisting erudition and memory, concentration and other executive functions [39, 40].

\subsection{Cardiovascular Effects}

Tachycardia is the most compatible and punctilious signs of acute action of cannabis, with augmented cardiac output and correspondingly augmented myocardial oxygen necessity [41]. In the cardiovascular system, both the cannabinoid receptors are found: CB1 and CB2 [42]. In teenage cannabis consumers, the intricacy differed from those presented by non-using patients of the same age [6]. Cannabis consumption can result in the high threat of myocardial infarction 4.8 fold in the hour after use, and stimulate angina in patients with heart disease [43].

\subsection{Respiratory Effects}

In most researches of cannabis smokers, chronic bronchitis takes place in truancy of COPD [44, 45]. After settling for tobacco consumption, chronic cannabis use is linked with an augmented frequency of syndromes of chronic bronchitis, and is compatible with damage and redness comprising the central airways [46]. In the U.S.A and New Zealand, the long-term studies revealed that usual cannabis smoker shows more manifestations of chronic bronchitis than non-smokers [47]. The damage in work of alveolar macrophages is also resulted by cannabis smoking and key to immune effector cells in the lung's protection against infection [48]. In compare to tobacco smokers, the cannabis smokers demonstrate shorten macrophage activity, in all likelihood because of the immunosuppressive activity of THC [49].

\subsection{Effects on Reproductive System}

Endocannabinoid signaling, mainly mediated by the CB2 receptor balance all crucial phases of pregnancy and affects pregnancy episodes. Signaling is also concerned in the maintenance of average sperm act, and thus male fertility [9]. A number of endocrine changes have been noticed in regular or heavy smokers of cannabis, comprising lessen testosterone levels and decreased sperm counts in males, and lessen luteinizing hormone and prolactin levels in the luteal stage of the menstrual cycle in females, causing shorter periods and more an ovulatory cycles [41].

\section{DISCUSSION}

As we all know that cannabis addiction is extending all over the world very rapidly. Even in some countries, they legalized it under a limited legal dose and other countries banned it completely. In India, the cannabis is illegal and also consumption and selling of cannabis is punishable under the Narcotics Drugs and Psychotropic Substances Act 1985. For imposition of death penalty in India for repeat offence, the minimum quantity to be seizure is $20 \mathrm{~kg}$ for Hashish and 500 grams for THC or ganja. It is legal in Netherlands, Uruguay, in the US states of Colorado, Oregon, Alaska and Washington. Cannabis is now becoming most abused drug because of its powerful effects. Also it is cheaper in cost and easily available drug. As we know that it grows everywhere in the world. Most of the drug peddlers see this as a great source of income or business point because most of the persons who consume cannabis are of youth or adult category. Even the number of youth who consume the cannabis are college or university students. The reason behind the fast increase of cannabis abusers among youth is myth and bad society. There is a myth in between the youngsters that consuming cannabis can inhibit the better concentration power during studies or in any work. This is completely a myth and because of this more and more youngsters falls under the influence of cannabis abuse. Various researches proved this wrong and validate it as a completely myth. Also, it has been seen that long chronic abusers becomes more violent in behavior and also feel irritation in society. The effects of marijuana differs from person to person, age and gender.

\section{CONClusion}

In terms of cannabis youth addiction, it is a topic of great concern and various serious steps needs to be taken towards solving this issues. Cannabis and its derivatives consumption 
making the young generation drug addict and as well as a criminal. It completely spoiling the career as well as physical health of youth. In worst effects of cannabis, it makes youth a criminal by making him violent in nature and also some youngsters started drug peddling in the sake of making money. Many laws and regulations has been made so far to prevent the consumption and trade of cannabis in different countries. Also, death penalty has been reported in China and Singapore related with cannabis trafficking. In India, youth especially of metropolitan cities becoming drug addict of cannabis and ruining their life for the enjoyment of few moments. The only conclusion of all researches and studies is that the cannabis makes a person weak, causes mental inability by its hallucinating effects and results in severe and irreversible harmful changes.

\section{REFERENCES}

[1] Schultes RE. Random thoughts and queries on the botany of cannabis. In: Joyce CRB, Curry SH, eds. The Botany and Chemistry of Cannabis. London: J \& A Churchill, 1970:11-38.

[2] Gloss D (2015). An overview of products and bias in research. Neurotherapeutics. 12(4):731-4.

[3] Timberlake DS. A comparison of drug use and dependence between blunt smokers and other cannabis Users. Subst Use Misuse. 2009; 44(3):401-415. Doi: 10.1080/10826080802347 651.

[4] Results from the 2015 National Survey on Drug Use and Health: Detailed Tables, SAMHSA, CBHSQ http://www.samhsa.gov/data/sites/def ault/files/NSDUH-DetTabs2015/NSDUH-Det Tabs-2015/NSDUH-DetTabs-2015.htm. Accessed October 11, 2016.

[5] Johnston L, O'Malley P, Miech R, Bachman J, Schulenberg J. Monitoring the Future National Survey Results on Drug Use: 1975-2016: Overview: Key Findings on Adolescent Drug Use. Ann Arbor, MI: Institute for Social Research, The University of Michigan; 2016.

[6] WHO Library Cataloguing-in-Publication Data The health and social effects of nonmedical cannabis use. 1.Cannabis - adverse effects. 2.Marijuana Smoking. 3.Marijuana Abuse. I. World Health Organization. ISBN 978924 151024 (who report)

[7] Elsohly MA, Slade D. Chemical constituents of marijuana: the complex mixture of natural cannabinoids. Life Sci. 2005 Dec 22; 78(5): 53948.

[8] Maldonado, R., Berrendero, F., Ozaita, A., \& R obeldo, P. (2011). Neurochemical basis of cann abis addiction. Neuroscience, 181:1-17.
[9] Madras, B. "Update of cannabis and its medical use." Report to the WHO Expert Committee on Drug Dependence (http://www.who.int/ medicines/access/controlled-substances/ 6_2_ cannabis_update.Pdf(201 5).

[10] Wall ME, Sadler BM, Brine D, Taylor H, Perez-Reyes M. Metabolism, disposition, and kinetics of $\Delta 9$-tetrahydrocannabinol in men and women. Clin Pharmacol Ther 1983;34:352-63

[11] Azorlosa JL, Heishman SJ, Stitzer ML, Mahaffey JM. Marijuana smoking: Effect of varying delta-9-tetrahydrocannabinol content and number of puffs. J Pharmacol Exp Ther 1992; 261: 114-122.

[12] Korte F, Haag M, Claussen U. Tetrahydrocannabinol-carbonsure, ein neuer Haschisch-Inhaltsstoff. Angew Chem 1966; 77:862.

[13] Claussen U, Korte F. ber das Verhalten von Hanf und von $\Delta 9-6 \alpha$, 10atranstetrahydrocannabinol beim Rauchen. Liebigs Ann Chem 1968; 713:162-5.

[14] Bloor RN, Wang TS, Spanel P, Smith D. Ammonia release from heated 'street' cannabis leaf and its potential toxic effects on cannabis users. Addiction. 2008 Oct; 103(10): 1671-7.

[15] Mattes RD, Shaw LM, Edling-Owens J, Engelman K, ElSohly MA. Bypassing the firstpass effect for the therapeutic use of cannabinoids. Pharmacol Biochem Behav 1993;44:745-7

[16] Lee D, Bergamaschi MM, Milman G, Barnes AJ, Queiroz RH, Vandrey R, Huestis MA. Plasma Cannabinoid Pharmacokinetics After Controlled Smoking and Ad libitum Cannabis Smoking in Chronic Frequent Users. J Anal Toxicol. 2015 Oct; 39(8): 580-7.

[17] Bergamaschi MM, Karschner EL, Goodwin RS, Scheidweiler KB, Hirvonen J, Queiroz RH, Huestis MA.Impact of prolonged cannabinoid excretion in chronic daily cannabis smokers' blood on per se drugged driving laws. Clin Chem. 2013; 59(3): 519-26.

[18] Maldonado, R., Berrendero, F., Ozaita, A., \& Robeldo, P. (2011). Neurochemical basis of can nabis addiction.Neuroscience, 181:1-17.

[19] Wang et al. (2016) One minute of marijuana secondhand smoke exposure substantially impairs vascular endothelial function. Journal of the American Heart Association. 5(8)

[20] Thomas et al. (2014) Adverse cardiovascular, cerebrovascular, and peripheral vascular effects of marijuana inhalation: what cardiologists need to know. American Journal of Cardiology 113(1): 187-90

[21] Mittleman MA, Lewis RA, Maclure M, Sherwood JB, Muller JE. Triggering Myocardial Infarction by Marijuana. 
Circulation 2001; 103(23):2805-2809. Doi: 10. 1161/01.CIR.103.23.2805

[22] Daling JR, Doody Dr, Sun X, etal. Association of marijuana use and the incidence of testicular germ cell tumors. Cancer. 2009: 115(6): 1215 (6):1215-1223. Doi:10.1002/cncr.24159

[23] Mackie K. Distribution of cannabinoid receptors in the central and peripheral nervous system. Handb Exp Pharmacol. 2005; (168): 299-325.

[24] Mena I, Dörr A, Viani S, Neubauer S, Gorostegui ME, Dörr MP (2013). Efectos del consumo de marihuana en escolares sobre funciones cerebrales demostrados mediante pruebas neuropsicológicas e imágenes de neuro-SPECT [Effects of consuming marijuana on school students' brain functions demonstrated through neuropsychological testing and neuro-SPECT imaging]. Salud mental. 36:367-74.

[25] Volkow ND, Wang GW, Telang F, Fowler JS, Alexoff D, Logan J, et al. (2014b). Decreased dopamine brain reactivity in marijuana abusers is associated with negative emotionality and addiction severity. Proc Natl Acad Sci U S A. 111(30):E3149-E3156.

[26] Meier et al. (2012) Persistent cannabis users show neuropsychological decline from childhood to midlife. Proceedings of the National Academy of Sciences USA 109(40): E2657-64.

[27] Chaperon F, Thiebot MH. Behavioral effects of cannabinoid agents in animals. Crit Rev Neurobiol 1999;13:243-81.

[28] Ranganathan M, D'Souza DC. The acute effects of cannabinoids on memory in humans: a review. Psychopharmacology (Berl). 2006 Nov; 188(4): 425-44.

[29] Schweinsburg AD, Brown, SA, \& Tapert, SF (2 008). The influence of cannabis use on neurocog nitive functioning in adolescents.Current Drug Abuse Reviews, 1:99-111.

[30] Siemens AJ. Effects of cannabis in combination with ethanol and other drugs. In: Petersen RC, ed. Marijuana Research Findings: 1980. NIDA Res Monogr Series 31. Washington: DHHS/ USPHS, 167-98.

[31] Martin WJ, Coffin PO, Attias E, Balinsky M, Tsou K, Walker JM. Anatomical basis for cannabinoid-induced antinociception as revealed by intracerebral microinjections. Brain Res 1999;822:237-42

[32] Leirer VO, Yesavage JA, Morrow DG. Marijuana carry-over effects on aircraft pilot performance. Aviat Space Environ Med. 1991 Mar; 62(3): 221-7.

[33] Matsuda LA, Lolait SJ, Brownstein MJ, Young AC, Bonner TI. Structure of a cannabinoid receptor and functional expression of the cloned cDNA. Nature. 1990 Aug 9; 346(6284): 561-4.

[34] Herkenham M, Lynn AB, Johnson MR, Melvin LS, de Costa BR, Rice KC. Characterization and localization of cannabinoid receptors in rat brain: a quantitative in vitro autoradiographic study. J Neurosci. 1991 Feb; 11(2): 563-83.

[35] Pazos MR, Núñez E, Benito C, Tolón RM, Romero J. Functional neuroanatomy of the endocannabinoid system. Pharmacol Biochem Behav. 2005 Jun; 81(2): 239-47.

[36] Pertwee RG. Endocannabinoids and Their Pharmacological Actions. Handb Exp Pharmacol. 2015; 231: 1-37.

[37] Huestis MA, Gorelick DA, Heishman SJ, Preston KL, Nelson RA, Moolchan ET, et al. (2001). Blockade of effects of smoked marijuana by the CB1-selective cannabinoid receptor antagonist SR141716. Arch Gen Psychiatry. 58(4):322-8.

[38] Iversen L (2012). How cannabis works in the human brain. In: Castle D, Murray R, D'Souza DC, editors. Marijuana and madness. Cambridge, Cambridge University Press:1-11.

[39] Pope HG, Gruber AJ, Hudson JI, Cohane G, Huestis MA, Yurgelun-Todd D (2003). Earlyonset cannabis use and cognitive deficits: what is the nature of the association? Drug Alcohol Depend. 69(3):303-10.

[40] Gruber SA, Sagar KA, Dahlgren MK, Racine M, Lukas SE (2012). Age of onset of marijuana use and executive function. Psychol Addict Behav. 26(3):496.

[41] H Kalant Medicinal use of cannabis. Pain Res Manage 2001; 6(2):80-91.

[42] The CB1 and CB2 cannabinoid receptors are both found in the cardiovascular system (Montecucco \& Di Marzo, 2012).

[43] Hall W \& Degenhard L (2009). Adverse health effects of non-medical cannabis use.Lancet, 37 4:1383139.

[44] Hancox RJ, Shin HH, Gray AR, Poulton R, Searson MR (2015). Effects of quitting cannabis on respiratory symptoms. Eur Respir J. 46(1):80-7.

[45] Kempker JA, Honig EG, Martin GS (2015). The effects of marijuana exposure on expiratory airflow. A study of adults who participated in the U.S. National Health and Nutrition Examination Study. Ann Am Thorac Soc. 12(2):135-141.

[46] Gates P, Jaffe A, Copeland J. Cannabis smoking and respiratory health: consideration of the literature. Respirology 2014; 19: 655-62.

[47] Tetrault, J.M., et al.Effects of cannabis smoking on pulmonary function and respiratory complic ations: a systematic review. Arch Intern Med 1 67, 221-228 (2007). 
[48] Baldwin GC, Tashkin DP, Buckley DM, Park AN, Dubinett SM, Roth MD (1997) Marijuana and cocaine impair alveolar macrophage function and cytokine production. Am J Respir Crit Care Med. 156(5):1606-13.
[49] Tashkin DP (2015). Does marijuana pose risks for chronic airflow obstruction? Ann Am Thorac Soc. 12(2):235-36.

Citation: Himanshu Yadav, Mahipal Singh Sankhla, Rajeev Kumar. Youth Becoming Addict of Cannabis and its Advancement at the Cost of Health. ARC Journal of Forensic Science. 2019 4(1): 20-25. http://dx.doi.org/ 10.20431/2456-0049.0401002

Copyright: (C) 2019 Authors. This is an open-access article distributed under the terms of the Creative Commons Attribution License, which permits unrestricted use, distribution, and reproduction in any medium, provided the original author and source are credited. 